\title{
Intrapreneurship concepts for engineers: a systematic review of the literature on its theoretical foundations and agenda for future research
}

\author{
Muhammad Zubair Alam*, Nadia Nasir and Ch. Abdul Rehman
}

\author{
*Correspondence: alam_zubair@ \\ hotmail.com \\ Department of Management \\ Science, Superior University, Lahore, \\ Pakistan
}

\begin{abstract}
Understanding of intrapreneurship as a phenomenon is somewhat fragmented and inconsistent especially in the case of engineers or engineering firms. This paper seeks to assess the relevant intellectual territory of intrapreneurship or corporate entrepreneurship (CE) by taking a systematic review of relevant research to collect insights into research linking intrapreneurship with engineering firms. The purpose of the systematic review is to identify key concepts in intrapreneurial research with regard to engineers or engineering firms as deliberated by researchers in literature. This systematic literature review (SLR) found that the academic interest of researchers on intrapreneurship has increased over the last decade with a diverse focus. Based on the findings of the review, this study has suggested various areas for future research on the conceptual framework of intrapreneurship, relationship of intrapreneurship with corporate performance, and intrapreneurship for engineers.
\end{abstract}

Keywords: Intrapreneurship, Corporate entrepreneurship, Engineering firms, Corporate culture, Engineering management, Systematic literature review

\section{Introduction}

Entrepreneurial actions can emerge at the individual or organisation level (Farrukh, Ying, \& Mansori, 2016). At an individual level, entrepreneurial start-ups occur, while at an organisation level, intrapreneurial mechanism evolves. Both entrepreneurial and intrapreneurial developments are essential for the economy (Shane \& Venkataraman, 2000). Intrapreneurship also known as corporate venturing or $\mathrm{CE}$ is defined as a phenomenon in which single or a group of employees instigate innovation or create new firms within the organisation (Sharma \& Chrisman, 2007). Intrapreneurship is authorising employees to use resources of the organisation to innovate changes within organisation and create a new business (Ağca, Topal, \& Kaya, 2012). New venture creation, the transformation of activities, and up-gradation of strategy are the organisational functions of intrapreneurship or CE (Stopford \& Baden-Fuller, 1994). Differing roles of engineering firms from other corporations have effects on the intrapreneurial capacities of employees

(c) The Author(s). 2020 Open Access This article is licensed under a Creative Commons Attribution 4.0 International License, which permits use, sharing, adaptation, distribution and reproduction in any medium or format, as long as you give appropriate credit to the original author(s) and the source, provide a link to the Creative Commons licence, and indicate if changes were made. The images or other third party material in this article are included in the article's Creative Commons licence, unless indicated otherwise in a credit line to the material. If material is not included in the article's Creative Commons licence and your intended use is not permitted by statutory regulation or exceeds the permitted use, you will need to obtain permission directly from the copyright holder. To view a copy of this licence, visit http://creativecommons.org/licenses/by/4.0/. 
(Blanka, 2018). The nature of engineering jobs sometimes restricts risk-taking by employees due to fear of failure.

Intrapreneurship is defined from the perspectives of (1) new venture related to ongoing product or service, (2) innovation in new products, services, technology or process through research and development, (3) initiatives of executives of organisation to encourage risk-taking, leading, aggressively seeking new opportunity to enhance competitive edge, (4) strategic revolution in organisation linked with culture of selfrenewal (Antoncic \& Hisrich, 2001). Intrapreneurial culture is helpful in supporting the organisation's development through the exploration of talent within the organisation and the cultivation of culture of innovation for entrepreneurial activities (Lukes \& Stephan, 2017). Intrapreneurial activities yield a much higher rate of success as compared to entrepreneurial start-ups. Shah, Gao, and Mittal (2014) reported success rate for start-ups as $20 \%$, whereas intrapreneurial predicted success rate can go up to $80 \%$.

Intrapreneurship empowers the organisations through being proactive in the market by searching and developing winning products and services using the potential of employs to create profitability and growth (Miles \& Covin, 2002). Risk-taking, competitive strategy and innovation are more established predictors of innovation in firms (Dess et al., 2003). The perceived outcomes of intrapreneurship as firm performance is somewhat differing domain due to its applicability in various contexts like engineering firms (Antoncic \& Hisrich, 2004). A detailed account of the similarities and differences between entrepreneurship and intrapreneurship are presented in Table 1.

Research on intrapreneurship for engineers and its impacts on engineering firms is still in its evolutionary phase and directions on various aspects in terms of exploration and testing of the phenomenon are rare. Previous research elaborated several aspects of intrapreneurship: (1) influence of intrapreneurship on firm performance (Augusto Felício, Rodrigues, \& Caldeirinha, 2012), (2) learning organisation phenomenon of intrapreneurship (Chawla \& Lenka, 2015; Kansikas \& Murphy, 2010), (3) personality trait of engineers and non-engineers as intrapreneurs (Alam, Kousar, Shabbir, \& Kaleem, 2020; Menzel, Aaltio, \& Ulijn, 2007; Williamson, Lounsbury, \& Han, 2013), (4) intrapreneurship competencies and development of measurement scale (Vargas-Halabí, MoraEsquivel, \& Siles, 2017), (5) relationship of intrapreneurship with employee engagement (Kassa \& Raju, 2015), (6) expansion of theoretical knowledge of intrapreneurship (Deprez \& Euwema, 2017; Williamson et al., 2013), and (7) global studies on intrapreneurship (Bosma, Stam, \& Wennekers, 2010). Few researchers have devoted attention to developing frameworks to test dimensions of intrapreneurship and its linkage with corporate performance (Augusto Felício et al., 2012; Chawla \& Lenka, 2015; Kassa \& Raju, 2015; Vargas-Halabí et al., 2017). On account of engineering firms and engineers, studies are rare as few researchers investigated intrapreneurial concepts and personality traits of engineers (Williamson et al., 2013). The scarcity of literature on aspects of engineers and engineering firms is restricted to intrapreneurship. While aspects of engineers and engineering firms in entrepreneurial context have been adequately studied by previous researchers as an appropriate research domain (Alam, Kousar, \& Rehman, 2019; Berglund \& Wennberg, 2006; Dabbagh \& Menascé, 2006; Del Vitto, 2008; DuvalCouetil, Shartrand, \& Reed, 2016; Souitaris, Zerbinati, \& Al-Laham, 2007). This SLR is first of its kind in which research so far conducted on aspects related to intrapreneurship of engineers and engineering firms have been reviewed. Various aspects of 
Table 1 Entrepreneurship and intrapreneurship

\begin{tabular}{l} 
Entrepreneurship \\
\hline Similarities \\
Recognition and definition of opportunity \\
Unique business strategy in innovative development of services and products \\
Motivated person or a team to materialize a concept into action \\
The requirement of balance and patience between all managerial affairs with a proactive approach and \\
passion \\
A concept that evolved for adoption and is in the formative stage, the vulnerability of change due to most \\
robust academic research \\
Opportunity always exists for successful capitalisation of concept \\
Customer focused approach with value creation \\
An ability by a person to encounter and clear resistances and explore creative ways in pursuit of problem- \\
solving or venture creation \\
Capability to encounter risk and counter through effective management \\
Significant vagueness exists in concept and execution
\end{tabular}

\section{Differences}

Entrepreneur takes risk

Entrepreneur owns the innovative idea or business concept

Entrepreneur owns the equity and ownership of all or much of the firm created out of entrepreneurial actions

Entrepreneur is the principal beneficiary and reward after success is unlimited; likewise, entrepreneur have to bear all forms of failures

More vulnerable to outside influences

A start-up entrepreneur can be quite independent although backed by a strong team

Entrepreneur has the flexibility of changing its course during entrepreneurial efforts

Entrepreneur can take speedy decisions

Entrepreneurs are less secure and less professional guidance is available due to limited circle

Limited or less than required resources are generally available with entrepreneurs

Entrepreneur has a limited scope at the earlier stage
Organisation as a whole assumes all kind of risks resulting out of innovative actions except risk on the career of an intrapreneur

Organisation benefits from the idea and intellectual property encompassing the concept

Intrapreneur shares little or no equity resulting out of the intrapreneurial venture

With regard to the case of success, intrapreneur or the team can be rewarded as per organisational policy; failures, however, are generally absorbed by the company and intrapreneur faces career risks in selected cases

Intrapreneur is protected as being within the organisation

Intrapreneur is typically very interdependent on many others with whom he or she needs to share credit

Intrapreneurs have limited flexibility and option to change course or use own intuition in pursuit of the goal as company policy will always take superiority

Long approval cycles are generally involved in case of intrapreneurial actions

Intrapreneurs are more secure due to job and associated benefits linked with network formed by the organisation including external and internal associates who can suggest or even bounce ideas

Organisation resources like finances, marketing force, distribution channels, R\&D, and customer base are available at the disposal of intrapreneur or team engaged in innovative development for the company

Intrapreneurial outcome has a greater amount of scope for rapid expansion at an increasingly faster pace due to organisational efforts

Source: (Hisrich \& Kearney, 2012; Morris, Kuratko, \& Covin, 2008) 
intrapreneurship like relationship with corporate performance, engineer's personality traits, and intrapreneurial actions by engineers have been deliberated.

The aims of this systematic review are to:

1. Understand the concept of intrapreneurship and its relevance to engineering organisations.

2. Identify core intrapreneurship or $\mathrm{CE}$ issues related to engineers and engineering firms being deliberated by researchers from existing research.

3. Identify areas of future research in intrapreneurship related to engineers and engineering organisations.

\section{Methods}

Intrapreneurship is a newer observable phenomenon as compared to entrepreneurship. Academicians have shown great interest in intrapreneurship research in recent years as evident from the rising number of publications in recent years (Fig. 1). The SLR is considered as a transparent, more focused, accessible, and clear method (Thorpe, Holt, Macpherson, \& Pittaway, 2005). Three stages of SLR, planning, conducting, and reporting (Tranfield, Denyer, \& Smart, 2003), have been separately carried out. Tranfield et al. (2003) process of the SLR is described in Fig. 2.

\section{SLR planning}

A review panel is employed to conduct the SLR in lines with recommendations of Tranfield et al. (2003). The review panel has been constituted after institutional approval and experts of innovation and entrepreneurship have been included. The methodology expert has also been included in the review panel to supervise the matters related to research methods. Panel review the objectives and formulate the scope of the

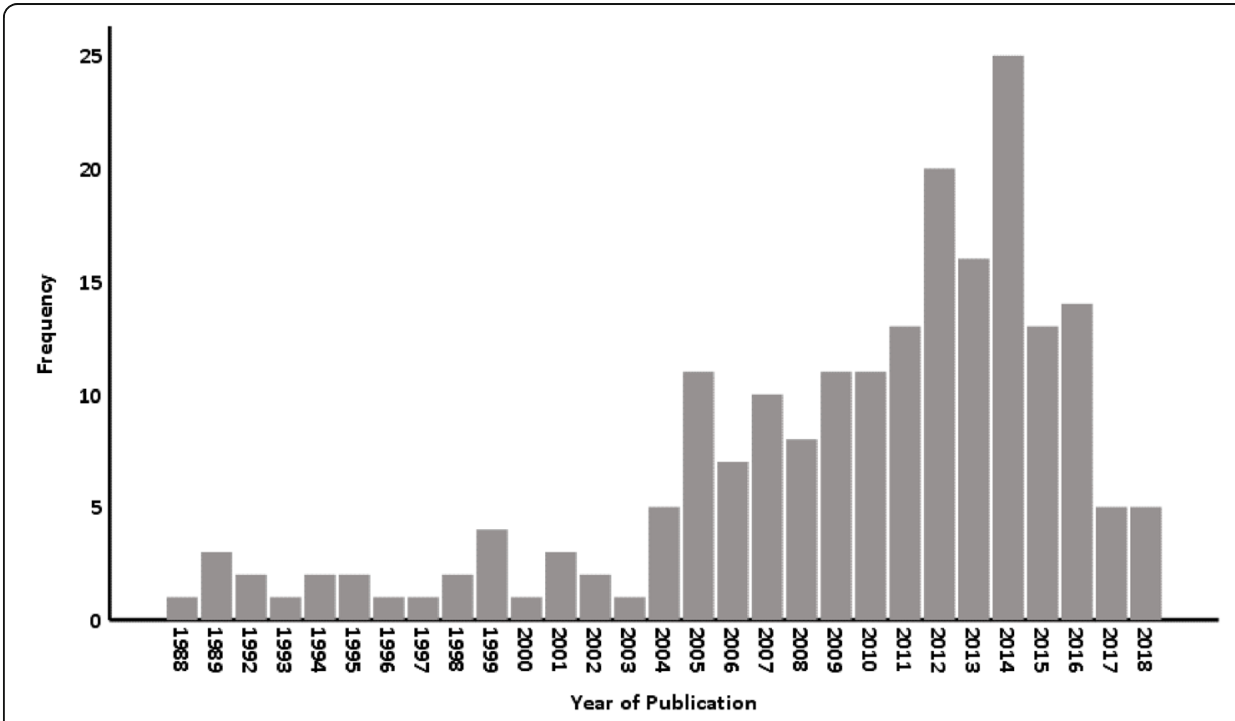

Fig. 1 The data for publication frequency has been complied after pooling studies for SLR from various databases. Year-wise presentation of data shows rising interest of researchers in various domains of intrapreneurship 
study after outlining the protocol of review. In the line of guidelines and process for review-based studies by Tranfield et al. (2003), review protocol was prepared to support the study which is appropriately structured to avoid the bias of researchers in the panel.

\section{Conducting the systematic review}

The search for sources was conducted in Scopus, which is an elaborated online database. Scopus, since its launch in 2004, is Elsevier's citation and abstract electronic database. Scopus covers content from 11,678 publishers. Most content in Scopus is from peer-reviewed journals and covers journals, books, and trade journals.

As compared to the Web of Science, Burnham (2006) has declared Scopus as relevantly easy to navigate for novice researchers. Scopus was selected due to high-quality abstracting and indexing that assists in search precise content. Due to multidisciplinary content availability in Scopus, researchers are facilitated in search of articles outside the researcher's discipline. The search for content in Scopus was employed from the year 1988 till 2020 on intrapreneurship related to firms with an emphasis on engineering or technology firms. The SLR can include books, theses, reports, book chapters, and online content including internal publications in line with recommendations of Tranfield et al. (2003). The present study, however, focused only on research articles from quality peer-reviewed journals due to emerging nature of intrapreneurship in firms.

\section{Criteria for source selection}

Intrapreneurship has gained significant attention in academic researchers, and numerous studies have been conducted on various dimensions. With regard to the mapping of studies and systematic review, little attempt has been done by researchers. Moreover, with regard to explaining the phenomenon for engineering firms and the education of

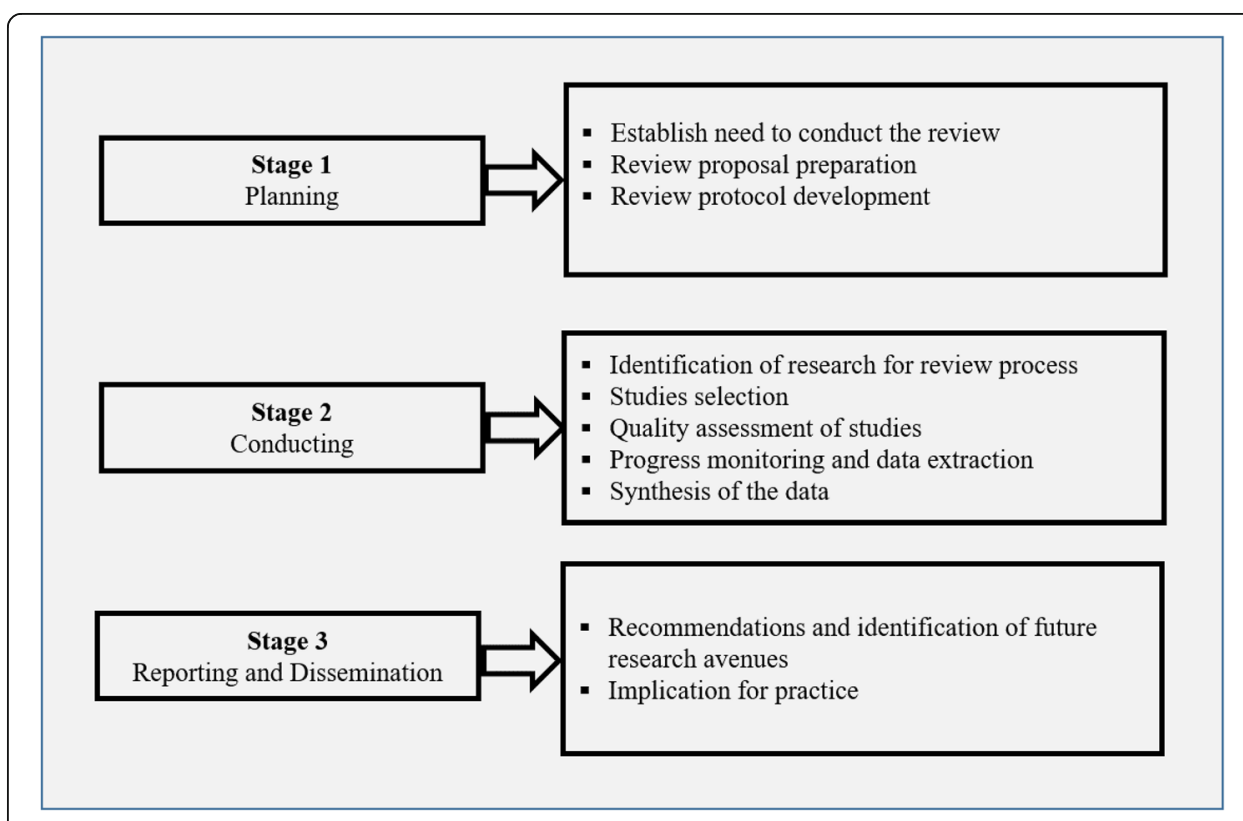

Fig. 2 The stages to conduct the SLR gives an idea of the overall process followed in this study 
engineers towards intrapreneurship, more primary studies are required to conduct the systematic review as studies in this particular area are rare. Hence, in order to explain the phenomenon of intrapreneurship and its relevance with engineering firms, the review panel has made an effort to carefully select those studies through inclusion and exclusion criteria (Tables 2 and 3), which can explain the phenomenon in a befitting manner. Being a novice area of research, a systematic review has been conducted to create a condition from where researchers can initiate and explore more about the topic and focus attention on bringing the state of maturity in the phenomenon of intrapreneurship.

After thorough deliberation and discussions among the review team and their subsequent discussions with experienced researchers in the area of entrepreneurship, the review team selected the following keywords: "intrapreneurship," "firm performance," "engineering," "organisation performance," and "learning organisation."

Thorpe et al. (2005) employed a two-stage approach to reduce the number of citations. The citations identified were reviewed as per specified inclusion and exclusion conditions (Tables 2 and 3). The titles of articles were analyzed as per exclusion criteria at first then followed by the analysis of abstracts according to inclusion criteria. The review panel read the complete paper where there was uncertainty as regards the relevance of the research study for the SLR. All efforts were done to achieve quality criteria specified by Thorpe et al. (2005). Research studies identified for review were categorised as quantitative, qualitative, conceptual, or theoretical.

\section{Results}

An overall summary of articles considered in the SLR is given in Table 4. The research articles in Table 4 are not presented in chronological order. These are listed according to relevance, importance, and overall impact on objectives of the study as perceived by the authors.

Researchers have used quantitative, qualitative, conceptual, pragmatic, and case study methods in explaining various aspects of intrapreneurial research. The intrapreneurial research domain of engineers and engineering firms revolve around (1) personality traits studies, (2) leadership expectations, (3) origin, role, identification of factors, and intrapreneurial concept, (4) outcomes of intrapreneurship and organisation performance, (5) pedagogy issues for engineers in intrapreneurship, (6) organisational internal and external effects, and (7) intrapreneurial differences between engineers and nonengineers in organisations.

Antoncic and Hisrich (2003) specified three focal areas of intrapreneurial research. The review articles explaining intrapreneurship dimensions and concepts related to engineers and engineering firms have been gathered under the focal areas. Table 5 summarizes research studies according to the focal areas of intrapreneurship.

\section{Findings and discussion}

As a whole, 27 articles have been reviewed. Findings from articles including various broad research directions with regard to intrapreneurship, corporate performance, and engineering firms are presented as review findings. The focus of previous academic researchers on intrapreneurship for engineers or firms is diverse and various topics are invariably recognised. This is because intrapreneurship or CE research is still an 
auxiliary of entrepreneurship. Newer interests of researchers in entrepreneurship influences areas for research in intrapreneurship. For example, innovativeness, risk-taking, and personality trait studies are much-established research areas in entrepreneurship, which is gaining a significant position in intrapreneurial or CE research. The findings and discussion are presented under sub-areas in which intrapreneurial research is being taken by academic researchers.

\section{Intrapreneurship actions by engineers}

Intrapreneurial actions by engineers have emerged as a research topic in intrapreneurship that is broader in scope with many sub-topics. In this regard, the role of engineers in firms, the role of motivation in intrapreneurial actions, risk-taking comparisons of intrapreneurial and entrepreneurial actions, engineer's role in innovation, environment, and culture as an antecedent of intrapreneurship, organisation factors, and sources are the topics that have been emphasised by academic researchers.

Technology has always remained linked to innovation which results from organisational intrapreneurial ventures. Engineers being the technical workforce have a role in innovation and creativity far prior to the inception of the phenomenon of intrapreneurship. Innovation in organisations is meaningful once it is coupled with social knowledge besides mere technical knowledge (Menzel et al., 2007). Social and technical innovation have a parallel role in technical organisations. To explore the intrapreneurship origin in engineering firms, Menzel et al. (2007) explored the role of engineering intrapreneur, organisational and managerial support for intrapreneurship. Intrapreneurship is of particular importance as the engineer's managerial role increases with career progression in firms. Engineers, who never become independent entrepreneur, still have to demonstrate an entrepreneurial role within organisation in lines with success of firms (Menzel et al. 2007).

There is an inherent difference in the motivation level of individuals towards intrapreneurship and entrepreneurship. Motivation studies on the intrapreneurial engagement of engineers are limited though research on motivation of engineers towards entrepreneurial intentions is more established (Alam et al., 2019). Menzel et al. (2007) mentioned that the sole beneficiary of entrepreneurial actions is individual. In the case of intrapreneurship, employers gain more benefits through financial gains out of innovation ventures within the organisation because of the intrapreneurial efforts of employees. Still, the aspect of motivation with regard to intrapreneurship is an underresearched area because studies highlighting the role of motivation in intrapreneurship are rare. Specific studies highlighting relationship of intrapreneurship with motivation was not found in various online databases.

Table 2 Inclusion criteria

\begin{tabular}{ll}
\hline Criteria & Reasons for inclusion \\
\hline All countries & $\begin{array}{l}\text { To gain a cross-cultural view of the phenomenon } \\
\text { of intrapreneurship }\end{array}$ \\
All dimensions of intrapreneurship & $\begin{array}{l}\text { To have a wide view of the phenomenon of } \\
\text { intrapreneurship }\end{array}$ \\
$\begin{array}{l}\text { Any type of research study (concept paper, } \\
\text { theoretical or empirical study) }\end{array}$ & To cover all existing studies \\
\hline
\end{tabular}


Table 3 Exclusion criteria

\begin{tabular}{|c|c|}
\hline Criteria & Reasons for exclusion \\
\hline Pre-1988 & $\begin{array}{l}\text { More than } 30 \text { years old studies will have less relevance in } \\
\text { the novice area of intrapreneurship }\end{array}$ \\
\hline $\begin{array}{l}\text { Book reviews, letters, magazines, newspaper } \\
\text { articles, conference papers, symposiums }\end{array}$ & High-quality peer-reviewed research has been focused \\
\hline Education, pedagogy, and practice & $\begin{array}{l}\text { Curriculum development studies and the effectiveness of } \\
\text { education related to entrepreneurship }\end{array}$ \\
\hline Entrepreneurship research & $\begin{array}{l}\text { To exclude research studies that primarily cover } \\
\text { entrepreneurship, intentions, motivations, education, and } \\
\text { business start-ups }\end{array}$ \\
\hline Psychology & $\begin{array}{l}\text { Research studies focusing on the psyche of individuals } \\
\text { and its assessment }\end{array}$ \\
\hline Comparative cross-cultural studies & $\begin{array}{l}\text { To exclude studies which are conducted for the purpose } \\
\text { of comparing various aspects in the different cultural } \\
\text { environment }\end{array}$ \\
\hline
\end{tabular}

As regards risk-sharing comparison in entrepreneurship and intrapreneurship, the entrepreneur has to bear more risk in case of failure of a business (Menzel et al., 2007). While in case of failure of innovative effort, intrapreneur will remain part of the same organisation. However, this failure can affect carrier progression (Manimala, Jose, \& Thomas, 2006). The role of employee rights in the form of unions and labor laws plays a role in protecting the career of the employee. Engineers are employed in firms on various technical roles where risk-taking can have effects far beyond control. Top management cannot authorise risk-taking by employees and intrapreneurial actions are restricted to innovative ideas in engineering firms. Cross-cultural studies in various organisations are necessary to evaluate the behaviour of employers towards the failure of innovation or intrapreneurial efforts in engineering firms.

Various studies have mentioned engineers as a key driver of innovation in science and technology (Ulijn \& Fayolle, 2004). Engineer's skills and ideas are a great source of technological development in existing companies. Rochester (2002) described that engineers have a diverse role in organisations from builders to problem solvers, in planning, in creation of technological artifacts, and above all in serving the society besides personal gains.

Menzel et al. (2007) described organisational factors for the development of intrapreneurial culture in engineering firms. Accordingly, the physical environment including workplace facilities designed to support a peaceful environment within the engineering firms is key towards the initiation of innovative ideas. Organisation hierarchical structure does play a great role in intrapreneurial ventures. McAdam and McClelland (2002) mentioned that flatter and flexible organisation structure is more influencing towards intrapreneurship. The availability of financial resources at the disposal of employees is also important to encourage employees towards risk-taking. Overall, top management's resolve dictates the culture of intrapreneurship and innovation (Huang \& Lin, 2006).

Organisation sources influencing intrapreneurship depend upon the overall organisational role concerning funding and planning for future ventures (Van de Ven \& Polley, 1992). Planning for the venture and its funding requirement should be a separate activity. Intrapreneurs need to focus on the development of innovative and doable plans without looking at financial requirements as finances come into play at a later stage. Financial constraints at an early stage in innovation development in engineering firms are 


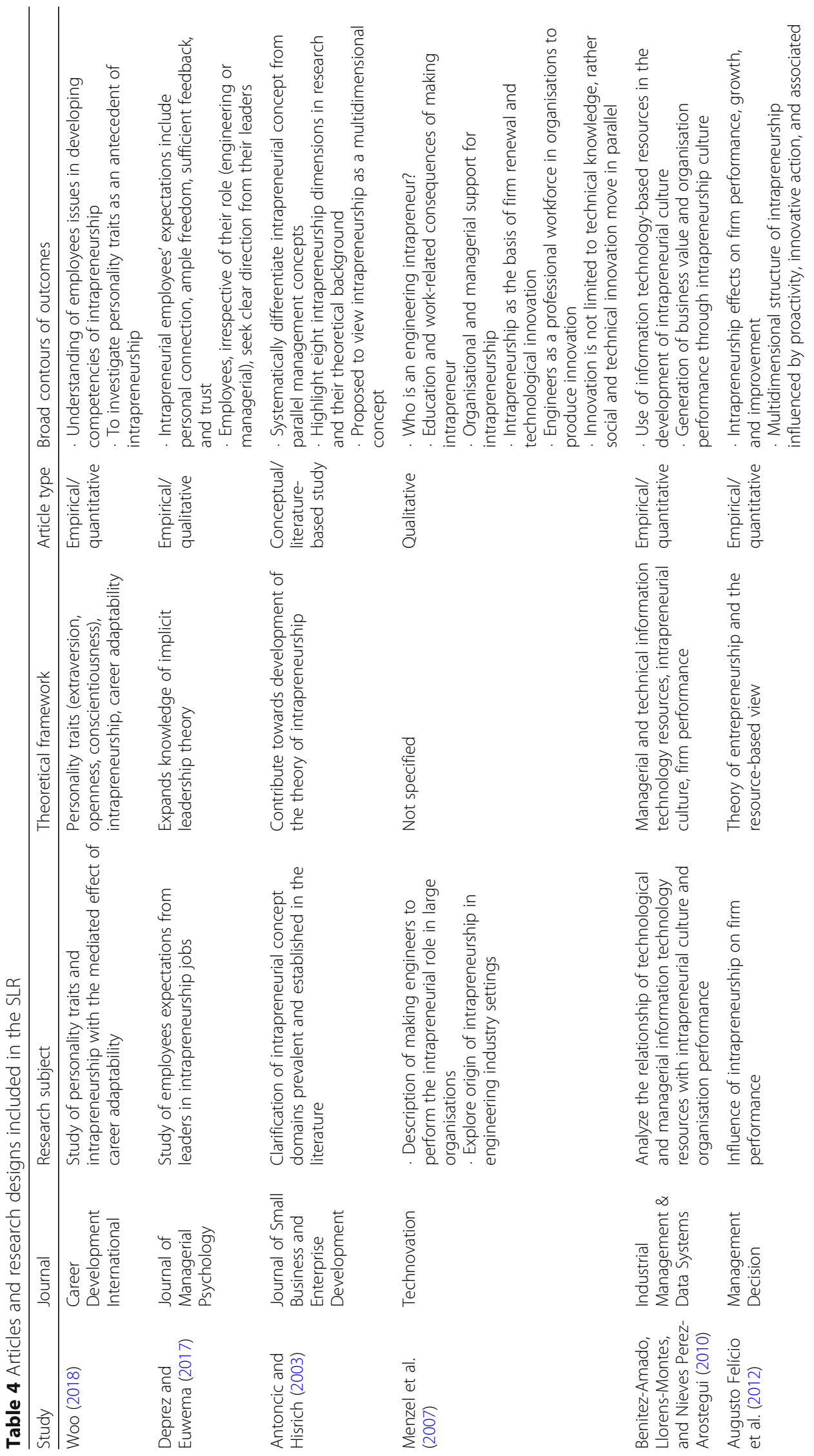




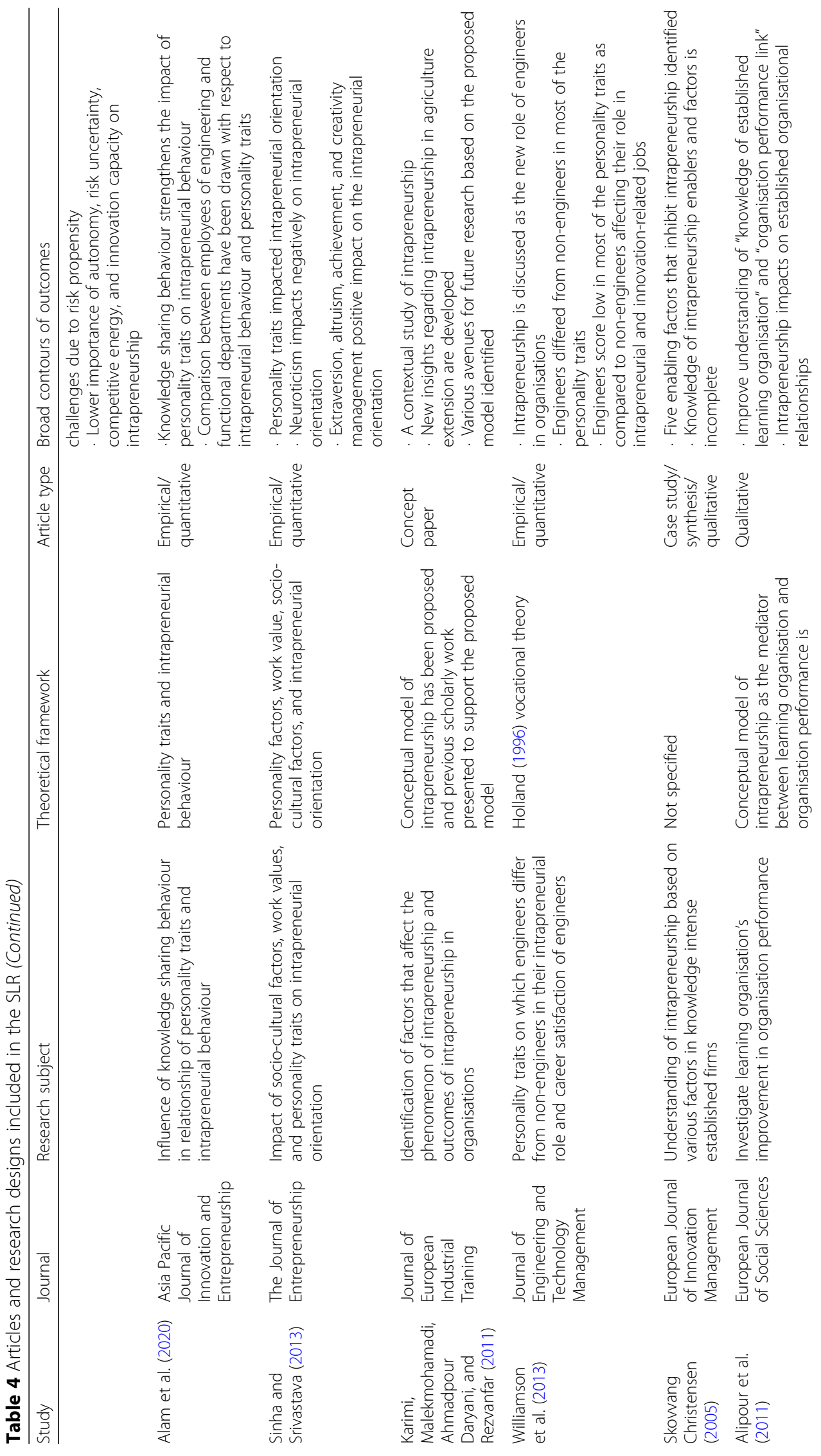




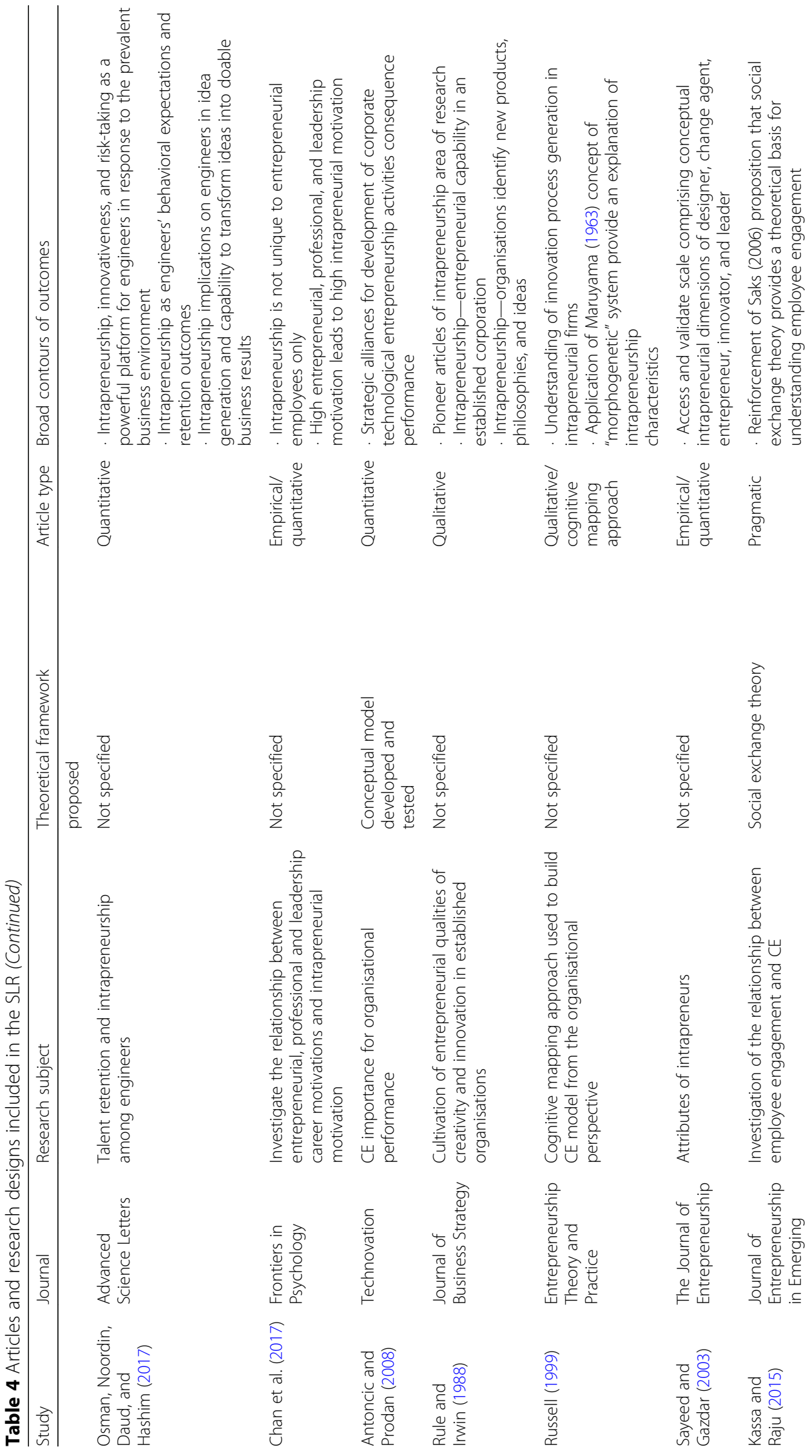




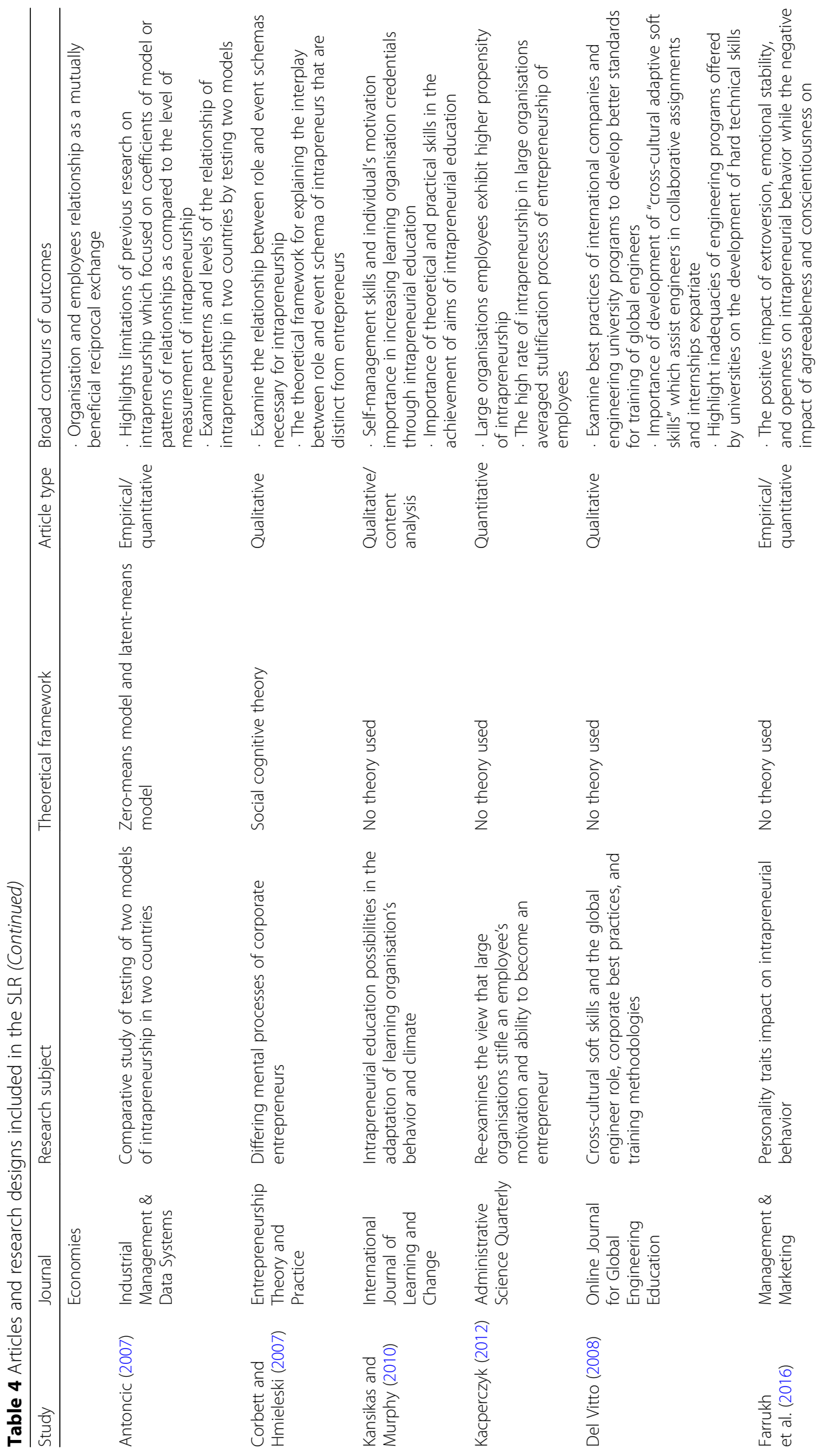




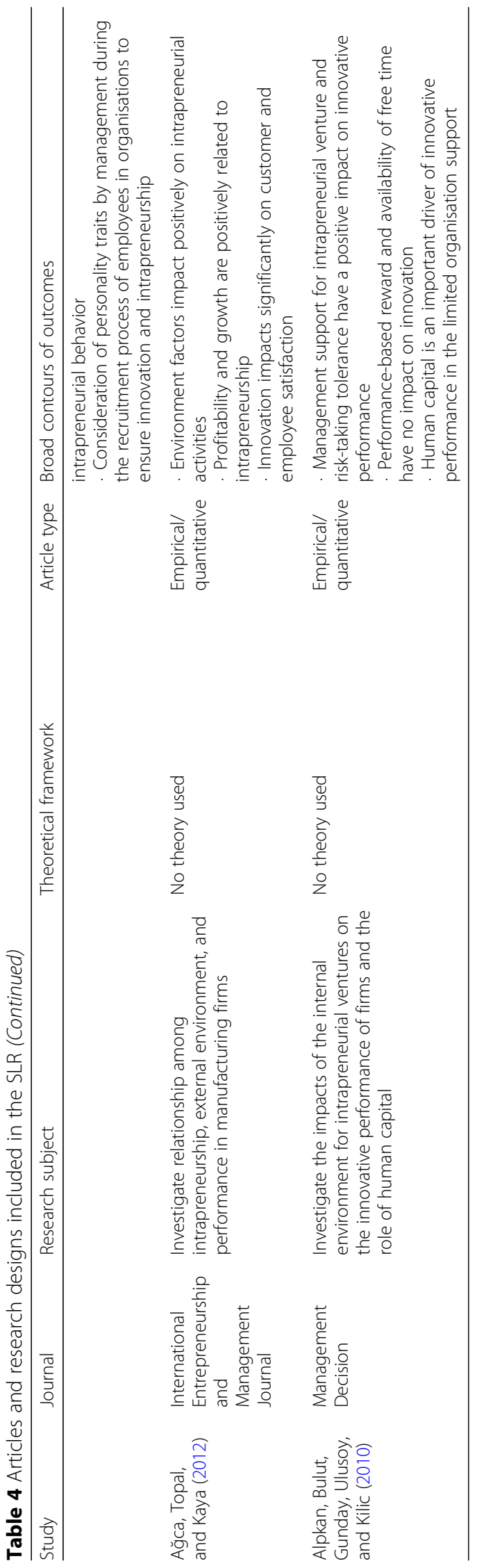


Table 5 Intrapreneurial research focal areas for engineers and engineering firms

\begin{tabular}{ll}
\hline Focal area & Citations from reviewed articles \\
\hline Individual intrapreneur characteristics, recognition, and support & Woo (2018) \\
& Antoncic and Hisrich (2003) \\
Sinha and Srivastava (2013) & Karimi et al. (2011) \\
Williamson et al. (2013) \\
Osman et al. (2017) \\
Formation of the new corporate venture, differentiation types, fit & Sayeed and Gazdar (2003) \\
with the organisation and corporate internal environment & Corbett and Hmieleski (2007) \\
& Farrukh et al. (2016) \\
& Benitez-Amado et al. (2010) \\
& Skovvang Christensen (2005) \\
Entrepreneurial organisation characteristics & Rule and Irwin (1988) \\
& Kansikas and Murphy (2010) \\
& Ağca et al. (2012) \\
& Alpkan et al. (2010) \\
& Deprez and Euwema (2017) \\
& Menzel et al. (2007) \\
& Augusto Felício et al. (2012) \\
Alipour et al. (2011) \\
Chan et al. (2017) \\
Antoncic and Prodan (2008) \\
Kassa and Raju (2015) \\
Antoncic (2007)
\end{tabular}

devastating for intrapreneurship. All kinds of optimizations can be done after maturing ideas, which come out as a vague sketch in the start. To teach engineering students to take the risk as intrapreneurs, the only way is learning by doing and learning from mistakes (Black, 1999).

\section{Personality traits of engineers towards intrapreneurship}

In entrepreneurship research "Big Five" or "Five Factor Model" is widely used (Fietze \& Boyd, 2017) and dominated the previous research on individual-level personality trait studies. In intrapreneurial research personality trait studies are getting significance in the context of engineers and engineering firms. This is because intrapreneurship is individual level endeavour as compared to CE (corporate level). At an individual level, the only tangible factor-affecting firms are personality traits. Various intrapreneurial studies have explained the personality trait of engineers and its outcomes on firms. Personality traits relationship with intrapreneurial behaviour is established in research (Woo, 2018) which stimulates creativity (Wang, 2010). The global marketplace and intensely competitive environment with the demand for innovation and creativity have made the organisational environment more challenging making human resource capital to undergo dramatic changes (Ağca et al. 2012). More demand for innovation processes in engineering firms has consequently enhanced engineering jobs way beyond technical practice. The enhanced role of engineers requires certain personality traits besides requisite knowledge and skills. Williamson et al. (2013) have carried out a study to compare personality traits between engineers and non-engineers. Engineers were found quite different in most of the personality traits.

The results of Williamson et al. (2013) studies mentioned that most of the personality traits are less favorable for engineers as compared to non-engineers. Engineers are low 
in extraversion (tendency to be expressive, talkative, and warm-heartedness) as compared to non-engineers. The findings of Williamson et al. (2013) studies were consistent with Watson and Clark (1997) studies that mentioned that engineers like attentive, thoughtful, and quiet environment for work without distractions being caused because of increased social interaction. It is because of the nature of the job which engineers generally handle requiring more focused and attentive settings at the workplace. Studies have also found that extraversion has a positive relationship with career satisfaction. Williamson et al. (2013) have argued that introvert personality is most suitable for studies like engineering. However, with change, job structure and over-enrichment of engineering jobs, according to the market environment, require more extravert personalities for a successful engineering career. So, a personality trait (introvert) which was found by researchers as more suitable for engineering education actually becomes a limitation for engineers in their professional career. Further investigation of personalities for engineers through exploratory studies can explain this interesting phenomenon. Besides comparison of engineers with non-engineers, extravert personalities have been found to have more satisfaction towards work and life in general due to more friendships with bosses and peers, acquaintanceships, and positive receptions at work place (Watson \& Clark, 1997).

Engineers are low on assertiveness (nature of persons to express themselves in ideas and opinions with confidence in a manner to defend personal beliefs, limiting selfinitiative and exert influence upfront but not in an aggressive manner) as compared to non-engineers (Williamson et al., 2013). Assertiveness has a positive relationship with career satisfaction for engineering professionals. The low assertiveness of engineers has already been established (Harmon, DeWitt, Campbell, \& Hansen, 1994) as engineers are considered low on the enterprising interest that is leadership, selling, and dominance. An assertive personality trait is more persuading career due to involvement in the organisation through increased interactions with colleagues, sharing of views, pitching in more challenging jobs, and looking for rises.

Williamson et al. (2013) have found engineers and non-engineer not significantly different on teamwork (tendency to work in a team cooperatively for mutual advantage) and visionary style (propensity to plan long-term and capability to envisage possibilities and contingencies of future). Teamwork for engineers is related to career satisfaction. The relationship between visionary style and career satisfaction is not established. In an enhanced engineering role, engineers are expected to be collaborative and interdisciplinary in teams of various diversity including racial, age, and ethnic.

Engineers are low on emotional stability (overall capacity to face job stress with workplace adjustment and resilience emotionally) as compared to non-engineers. Emotional stability has a strong relationship with career satisfaction. In engineering jobs, workplace stress is more due to the complexity of tasks, stiff deadlines, numerous unsaid demands, and high stakes in case of failure. Overall, workplace stress in engineering jobs significantly lowers emotional stability.

Openness (having hopeful outlook in different situations, prospects and tend to persist in setbacks to minimize problems) is considered as most highly related to career satisfaction for engineers as compared to non-engineers (Williamson et al., 2013). Engineers are lower on openness as compared to non-engineers that is due to various factors including workplace stress, outsourcing tendency in the organisation related to 
engineering jobs (Bryant, 2006), and more optimistic nature of other occupations in same organisation due to their nature of the job.

Williamson et al. (2013) found engineers lower in customer service orientation (quality service provision with a highly personalized response to achieve a higher level of customer satisfaction way beyond normal policy and job description) as compared to non-engineers. The satisfaction of all kinds of customers is key in the pursuit of more intrapreneurial roles for engineers (Menzel et al., 2007).

Work drive (capacity to work for extended hours in an irregular timetable; tendency to invest more energy and focus on job and career as self-motivated; propensity to meet deadlines, job success achievement, and ability to finish projects) is second highly related to career satisfaction after openness (Williamson et al., 2013). Engineers are lower on the work drive as compared to other occupants. Engineers who found to score more on work drive were more satisfied with their job. Researchers have been unable to explain the low score of engineers on the work drive (Lounsbury \& Gibson, 2002). This phenomenon of low work drive is even more depressing and unfortunate for engineers as "hard work" is the key propensity of engineers in all entrepreneurial and intrapreneurial jobs (Dryburgh, 1999). Engineering jobs are becoming such in which engineers need to have the capacity to learn fast the complex engineering features for swift application on projects. Within this intense environment, still, engineers are scoring low on work drive dictates a lack of understanding of various dimensions of the phenomenon of work drive for engineering professionals. More exploratory studies are required to fully explain the phenomenon of work drive for engineers. Engineers also found low on image management (disposition of people to observe, control, and monitor the selfimage while interacting with people in a befitting manner) that is negatively related to career satisfaction.

\section{Intrapreneurship and firm performance}

Intrapreneurship's association with firm performance was not established (Antoncic \& Hisrich, 2004), though various factors like innovativeness, risk-taking, and proactiveness have been frequently tested by researchers (Dess et al., 2003). Researchers have considered it important to study intrapreneurship in the perspective of firm performance (Hornsby, Kuratko, \& Zahra, 2002). Augusto Felício et al. (2012) have carried out the study for understanding the impact of intrapreneurship on firm performance to examine the influence of factors like productivity, growth, and financial performance on intrapreneurship. Intrapreneurial risk-taking in organisations will be more when managers perceive good tolerance in organisations for risks and mistakes resulting out from innovations efforts (Gómez-Haro, Aragón-Correa, \& Cordón-Pozo, 2011).

Intrapreneurship has long been considered as a school within the entrepreneurial theory, and by assuming entrepreneurial spirit as the existence of companies, intrapreneurship is a mean to rejuvenate firms (Stopford \& Baden-Fuller, 1990). The purpose of intrapreneurship is to harness the entrepreneurial culture of large firms with those of small firms as large firms have established space for intrapreneurial tasks and risktaking (McGinnis \& Verney, 1987). Researchers have attempted to theorize the domain of intrapreneurship from various perspectives, there still exists a need to establish the 
relationship between firm performance and intrapreneurship (Dess et al., 2003) as research studies have not been able to fully explore the relationship.

Intrapreneurship strengthens the competencies in firms as a role played in the form of innovation and skills in achieving knowledge becomes a competitive advantage for firms (Hornsby et al., 2002). This competitive advantage lies in organisational resources that include employee's aptitude and capabilities through intangible resources (Grant, 1991). Hence, the theoretical perspective of the resource-based view reflects intrapreneurship as an element of conversion and utilization of resources for organisational advantage (Floyd \& Wooldridge, 1999). Corporate resources are important in the development and existence of new products and services that entrepreneurs develop in organisations in support of firm development (Kakati, 2003).

Various researchers have established conceptual and empirical studies that report the relationship between intrapreneurship and firm performance as regards small and medium-sized companies (Antoncic \& Hisrich, 2001; Champathes Rodsutti \& Swierczek, 2002; Wiklund \& Shepherd, 2003). In the case of developed economies, intrapreneurship has a positive relationship with corporate performance (Hornsby et al., 2002; Lumpkin \& Dess, 2001). Intrapreneurship's various dimensions can vary in terms of their relationship with corporate performance; innovative capacity and pro-activeness have a relationship with growth (Kreiser, Marino, \& Weaver, 2002; Zahra \& Nielsen, 2002).

Within an organisation, risk-taking through the exploitation of organisational resources can be greatly uncertain for employees (Keh, Der Foo, \& Lim, 2002). Initiative taking in the organisation by persons as regards intrapreneurial action reflects dominance and a combination of many other aggressive actions. New products and services because of intrapreneurial actions face complex competition as these are introduced ahead of market demand through anticipation. Innovation is the propensity to contribute to creative processes by developing and testing novel ideas that can result in the formation of new products, services, or methods (Augusto Felício et al. 2012). All these factors like innovation, risk-taking and developments in the form of new products and services affect the performance of firms invariably. Increased risks and uncertainty can be due to more innovation processes in organisations.

As regards the influence of innovation on firm performance, researchers reported mixed results. Heunks (1998) reported that firm performance does not influence innovation processes in organisations. Vermeulen, De Jong, and O'shaughnessy (2005) reported that innovation influence negatively on firm performance while Guo, Lev, and Zhou (2005) and Huarng and Hui-Kuang Yu (2011) reported a positive relationship between innovation and firm performance. Few studies suggested a moderated relationship between innovation and firm performance (Li \& Atuahene-Gima, 2001; Thornhill, 2006).

The review panel identified six factors that can explain intrapreneurship. These factors are: (1) competitive energy, (2) innovation, (3) risk/uncertainty, (4) pro-activeness, (5) risk/challenges, (6) autonomy. The results of studies of Augusto Felício et al. (2012) conducted on Portuguese companies can also be applied to other contexts based on small and medium-sized enterprises while studying the relationship between performance and innovation. Research progress on the relationship between intrapreneurship 
and firm performance is still in the exploratory and theoretical stage. Existing theoretical frameworks cannot sufficiently explain intrapreneurship as most research studies have provided basic and general knowledge about the phenomenon adopting contradictory principles.

\section{Conclusion}

This SLR has identified various areas that require the attention of academic researchers. This SLR identified various gaps in intrapreneurial research as per the objectives of the study. The first gap is related to the relationship between motivation and intrapreneurship, as studies highlighting the role of motivation in intrapreneurship are rare. Although more established research is available on motivation and entrepreneurship (Alam et al., 2019). Various research studies have also reported this area in future research directions.

Secondly, cross-cultural studies to evaluate the behavior of employees towards intrapreneurship in engineering firms are also rare. This is a major gap in research of intrapreneurship as many intrapreneurial outputs like innovative and creative products are evident.

Personality trait research of engineering intrapreneurs is an interesting research area. Each type of personality trait needs exploratory researches. Cross-cultural studies on the personality trait of engineers will yield interesting results.

Though engineering jobs are intense due to various factors, yet engineers are found low on the work drive as identified during the review. Existing research has not been able to explain the phenomenon and exploratory studies are required on the work drive of engineers.

Research on the relationship between intrapreneurship and firm performance is in the exploratory stage. Existing theoretical frameworks are not sufficient to explain the relationship dimensions as previous research findings are complex and contradictory.

There is potential for additional studies relating to the relationship between the personality traits of engineers with other concepts and variables. Research on the relationship of personality traits with career success or measure of productivity will be interesting to study by researchers as part of research on personality traits. Additionally, personality profile comparison of engineering and non-engineering managers can be useful to get insights into personality trait studies.

\section{Abbreviations}

CE: Corporate entrepreneurship; R\&D: Research and development; SLR: Systematic literature review

\section{Acknowledgements}

The authors acknowledge the support extended by Superior University, Lahore, Pakistan, by providing expert panels and supervisory support, whenever required during all phases of the SLR.

Authors' contributions

MZA conceived the study and recommended the parameter of the study in consultation with NN. The research design was finalized after the approval of CAR. NN carried out an initial search of all relevant studies pertaining to the area of research from various sources as mentioned in the manuscript for presentation and finalization by the review panel. MZA had written the introduction, findings, and conclusions of the study. MZA carried out a detailed study of all relevant studies for inclusion in the SLR. CAR coordinated institutional supports and overall supervised the study and approved the write-up. The author(s) read and approved the final manuscript. 


\section{Availability of data and materials}

Data sharing is not applicable to this article as no datasets were generated or analyzed during the current study. However, the authors state that all kinds of research studies (cited research articles and endnote file) are available from the Journal of Innovation and Entrepreneurship during the review process. No quantitative or statistical analysis has been done due to the nature of the study; hence, statistical data is not available.

\section{Competing interests}

The authors declare that they have no competing interests.

Received: 13 June 2019 Accepted: 6 March 2020

Published online: 20 April 2020

\section{References}

Ağca, V., Topal, Y., \& Kaya, H. (2012). Linking intrapreneurship activities to multidimensional firm performance in Turkish manufacturing firms: An empirical study. International Entrepreneurship and Management Journal, 8(1), 15-33.

Alam, M. Z., Kousar, S., \& Rehman, C. A. (2019). Role of entrepreneurial motivation on entrepreneurial intentions and behaviour: Theory of planned behaviour extension on engineering students in Pakistan. Journal of Global Entrepreneurship Research, 9(1), 1-20. https://doi.org/10.1186/s40497-019-0175-1.

Alam, M. Z., Kousar, S., Shabbir, A., \& Kaleem, M. A. (2020). Personality traits and intrapreneurial behaviour: Moderated role of knowledge sharing behaviour in diverse group of employees in developing country. Asia Pacific Journal of Innovation and Entrepreneurship, ahead-of-print. https://doi.org/10.1108/APJIE-09-2019-0068

Alipour, F., Idris, K., Ismail, I. A., Uli, J. A., \& Karimi, R. (2011). Learning organization and organizational performance: mediation role of intrapreneurship. European Journal of Social Sciences, 21(4), 547-555.

Alpkan, L., Bulut, C., Gunday, G., Ulusoy, G., \& Kilic, K. (2010). Organizational support for intrapreneurship and its interaction with human capital to enhance innovative performance. Management Decision, 48(5), 732-755.

Antoncic, B. (2007). Intrapreneurship: A comparative structural equation modeling study. Industrial Management \& Data Systems, 107(3), 309-325.

Antoncic, B., \& Hisrich, R. D. (2001). Intrapreneurship: Construct refinement and cross-cultural validation. Journal of Business Venturing, 16(5), 495-527.

Antoncic, B., \& Hisrich, R. D. (2003). Clarifying the intrapreneurship concept. Journal of Small Business and Enterprise Development, 10(1), 7-24

Antoncic, B., \& Hisrich, R. D. (2004). Corporate entrepreneurship contingencies and organizational wealth creation. Journal of Management Development, 23(6), 518-550

Antoncic, B., \& Prodan, I. (2008). Alliances, corporate technological entrepreneurship and firm performance: Testing a model on manufacturing firms. Technovation, 28(5), 257-265.

Augusto Felício, J., Rodrigues, R., \& Caldeirinha, V. R. (2012). The effect of intrapreneurship on corporate performance. Management Decision, 50(10), 1717-1738

Benitez-Amado, J., Llorens-Montes, F. J., \& Nieves Perez-Arostegui, M. (2010). Information technology-enabled intrapreneurship culture and firm performance. Industrial Management \& Data Systems, 110(4), 550-566.

Berglund, H., \& Wennberg, K. (2006). Creativity among entrepreneurship students: Comparing engineering and business education. International Journal of Continuing Engineering Education and Life Long Learning, 16(5), 366-379.

Black, J. S. (1999). Globalizing people through international assignements. Addison-Wesley.

Blanka, C. (2018). An individual-level perspective on intrapreneurship: a review and ways forward. Review of Managerial Science, 13(5), 919-961.

Bosma, N., Stam, E., \& Wennekers, A. (2010). Intrapreneurship-An international study. In EIM Research Reports, H2010005.

Bryant, P. T. (2006). Decline of the engineering class: Effects of global outsourcing of engineering services. Leadership and Management in Engineering, 6(2), 59-71.

Burnham, J. F. (2006). Scopus database: A review. Biomedical Digital Libraries, 3(1), 1.

Champathes Rodsutti, M., \& Swierczek, F. W. (2002). Leadership and organizational effectiveness in multinational enterprises in southeast Asia. Leadership and Organization Development Journal, 23(5), 250-259.

Chan, K.-Y., Ho, M.-H. R., Kennedy, J. C., Uy, M. A., Kang, B. N., Chernyshenko, O. S., \& Yu, K. Y. T. (2017). Who wants to be an intrapreneur? Relations between employees' entrepreneurial, professional, and leadership career motivations and intrapreneurial motivation in organizations. Frontiers in Psychology, 8, 2041.

Chawla, S., \& Lenka, U. (2015). A study on learning organizations in Indian higher educational institutes. Journal of Workplace Learning, 27(2), 142-161.

Corbett, A. C., \& Hmieleski, K. M. (2007). The conflicting cognitions of corporate entrepreneurs. Entrepreneurship theory and practice, 31(1), 103-121.

Dabbagh, N., \& Menascé, D. A. (2006). Student perceptions of engineering entrepreneurship: An exploratory study. Journal of Engineering Education, 95(2), 153-164.

Del Vitto, C. (2008). Cross-cultural "soft skills" and the global engineer: Corporate best practices and trainer methodologies. Online Journal for Global Engineering Education, 3(1), 1-9.

Deprez, J., \& Euwema, M. (2017). You can't always get what you want? Leadership expectations of intrapreneurs. Journal of Managerial Psychology, 32(6), 430-444.

Dess, G. G., Ireland, R. D., Zahra, S. A., Floyd, S. W., Janney, J. J., \& Lane, P. J. (2003). Emerging issues in corporate entrepreneurship. Journal of Management, 29(3), 351-378.

Dryburgh, H. (1999). Work hard, play hard: Women and professionalization in engineering-adapting to the culture. Gender and Society, 13(5), 664-682.

Duval-Couetil, N., Shartrand, A., \& Reed, T. (2016). The role of entrepreneurship program models and experiential activities on engineering student outcomes. Advances in Engineering Education, 5(1), 1-27.

Farrukh, M., Ying, C. W., \& Mansori, S. (2016). Intrapreneurial behavior: An empirical investigation of personality traits. Management and Marketing, 11(4), 597-609. 
Fietze, S., \& Boyd, B. (2017). Entrepreneurial intention of Danish students: a correspondence analysis. International Journal of Entrepreneurial Behavior and Research, 23(4), 656-672.

Floyd, S. W., \& Wooldridge, B. (1999). Knowledge creation and social networks in corporate entrepreneurship: The renewal of organizational capability. Entrepreneurship Theory and Practice, 23(3), 123-144.

Gómez-Haro, S., Aragón-Correa, J. A., \& Cordón-Pozo, E. (2011). Differentiating the effects of the institutional environment on corporate entrepreneurship. Management Decision, 49(10), 1677-1693.

Grant, R. M. (1991). The resource-based theory of competitive advantage: Implications for strategy formulation. California Management Review, 33(3), 114-135.

Guo, R.-J., Lev, B., \& Zhou, N. (2005). The valuation of biotech IPOs. Journal of Accounting, Auditing \& Finance, 20(4), 423-459.

Harmon, L. W., DeWitt, D. W., Campbell, D. P., \& Hansen, J.-I. C. (1994). Strong interest inventory: Applications and technical guide: form T317 of the Strong vocational interest blanks. Stanford University Press.

Heunks, F. (1998). Innovation, creativity and success, small business economics. The Netherlands: Kluwer Academic Publishers.

Hisrich, R. D., \& Kearney, C. (2012). Corporate entrepreneurship: How to create a thriving entrepreneurial spirit throughout your company. New York: McGrlaw-Hill.

Holland, J. L. (1996). Exploring careers with a typology: What we have learned and some new directions. American Psychologist, 51(4), 397-410.

Hornsby, J. S., Kuratko, D. F., \& Zahra, S. A. (2002). Middle managers' perception of the internal environment for corporate entrepreneurship: Assessing a measurement scale. Journal of Business Venturing, 17(3), 253-273.

Huang, E. Y., \& Lin, S.-C. (2006). How R\&D management practice affects innovation performance: An investigation of the hightech industry in Taiwan. Industrial Management \& Data Systems, 106(7), 966-996.

Huarng, K.-H., \& Hui-Kuang Yu, T. (2011). Entrepreneurship, process innovation and value creation by a non-profit SME. Management Decision, 49(2), 284-296.

Kacperczyk, A. J. (2012). Opportunity structures in established firms: Entrepreneurship versus intrapreneurship in mutual funds. Administrative Science Quarterly, 57(3), 484-521.

Kakati, M. (2003). Success criteria in high-tech new ventures. Technovation, 23(5), 447-457.

Kansikas, J., \& Murphy, L. (2010). Students' perceptions on intrapreneurship education—prerequisites for learning organisations. International Journal of Learning and Change, 4(1), 49-63.

Karimi, A., Malekmohamadi, I., Ahmadpour Daryani, M., \& Rezvanfar, A. (2011). A conceptual model of intrapreneurship in the Iranian agricultural extension organization: Implications for HRD. Journal of European Industrial Training, 35(7), 632-657.

Kassa, A. G., \& Raju, R. S. (2015). Investigating the relationship between corporate entrepreneurship and employee engagement. Journal of Entrepreneurship in Emerging Economies, 7(2), 148-167.

Keh, H. T., Der Foo, M., \& Lim, B. C. (2002). Opportunity evaluation under risky conditions: The cognitive processes of entrepreneurs. Entrepreneurship Theory and Practice, 27(2), 125-148.

Kreiser, P. M., Marino, L. D., \& Weaver, K. M. (2002). Assessing the psychometric properties of the entrepreneurial orientation scale: A multi-country analysis. Entrepreneurship Theory and Practice, 26(4), 71-93.

Li, H., \& Atuahene-Gima, K. (2001). Product innovation strategy and the performance of new technology ventures in China. Academy of Management Journal, 44(6), 1123-1134.

Lounsbury, J., \& Gibson, L. (2002). Personal Style Inventory: A work-based personality measurement system. Knoxville: Resource Associates.

Lukes, M., \& Stephan, U. (2017). Measuring employee innovation: a review of existing scales and the development of the innovative behavior and innovation support inventories across cultures. International Journal of Entrepreneurial Behavior \& Research, 23(1), 136-158.

Lumpkin, G. T., \& Dess, G. G. (2001). Linking two dimensions of entrepreneurial orientation to firm performance: The moderating role of environment and industry life cycle. Journal of Business Venturing, 16(5), 429-451.

Manimala, M. J., Jose, P., \& Thomas, K. R. (2006). Organizational constraints on innovation and intrapreneurship: Insights from public sector. Vikalpa, 37(1), 49-50.

Maruyama, M. (1963). The second cybernetics: Deviation-amplifying mutual causal processes. American Scientist, 51(2), 164179.

McAdam, R., \& McClelland, J. (2002). Sources of new product ideas and creativity practices in the UK textile industry. Technovation, 22(2), 113-121.

McGinnis, M. A., \& Verney, T. P. (1987). Innovation management and intrapreneurship. SAM Advanced Management Journal, 52(3), 19-23.

Menzel, H. C., Aaltio, I., \& Ulijn, J. M. (2007). On the way to creativity: Engineers as intrapreneurs in organizations. Technovation, 27(12), 732-743. https://doi.org/10.1016/j.technovation.2007.05.004.

Miles, M. P., \& Covin, J. G. (2002). Exploring the practice of corporate venturing: Some common forms and their organizational implications. Entrepreneurship Theory and Practice, 26(3), 21-40.

Morris, M., Kuratko, D., \& Covin, J. (2008). Corporate entrepreneurship and innovation. Mason: Thomson/South Western Publishers.

Osman, I., Noordin, F., Daud, N., \& Hashim, M. J. M. (2017). Intrapreneurship and talent retention among engineers in the Malaysian private organisations. Advanced Science Letters, 23(1), 514-518. https://doi.org/10.1166/asl.2017.7240.

Rochester, J. (2002). Becoming a professional-education is only the beginning. IEEE-USA Today's Engineer.

Rule, E. G., \& Irwin, D. W. (1988). Fostering intrapreneurship: The new competitive edge. Journal of Business Strategy, 9(3), 4447.

Russell, R. D. (1999). Developing a process model of intrapreneurial systems: A cognitive mapping approach. Entrepreneurship Theory and Practice, 23(3), 65-84.

Sayeed, O. B., \& Gazdar, M. K. (2003). Intrapreneurship: assessing and defining attributes of intrapreneurs. The Journal of Entrepreneurship, 12(1), 75-89.

Shah, R., Gao, Z., \& Mittal, H. (2014). Innovation, entrepreneurship, and the economy in the US, China, and India: Historical perspectives and future trends. Academic Press.

Shane, S., \& Venkataraman, S. (2000). The promise of entrepreneurship as a field of research. Academy of Management Review, 25(1), 217-226. 
Sharma, P., \& Chrisman, S. J. J. (2007). Toward a reconciliation of the definitional issues in the field of corporate entrepreneurship. In Entrepreneurship (pp. 83-103). Springer.

Sinha, N., \& Srivastava, K. B. (2013). Association of personality, work values and socio-cultural factors with intrapreneurial orientation. The Journal of Entrepreneurship, 22(1), 97-113.

Skovvang Christensen, K. (2005). Enabling intrapreneurship: The case of a knowledge-intensive industrial company. European Journal of Innovation Management, 8(3), 305-322.

Souitaris, V., Zerbinati, S., \& Al-Laham, A. (2007). Do entrepreneurship programmes raise entrepreneurial intention of science and engineering students? The effect of learning, inspiration and resources. Journal of Business Venturing, 22(4), 566-591.

Stopford, J. M., \& Baden-Fuller, C. (1990). Corporate rejuvenation. Journal of Management Studies, 27(4), 399-415.

Stopford, J. M., \& Baden-Fuller, C. W. (1994). Creating corporate entrepreneurship. Strategic Management Journal, 15(7), 521536.

Thornhill, S. (2006). Knowledge, innovation and firm performance in high-and low-technology regimes. Journal of Business Venturing, 21(5), 687-703.

Thorpe, R., Holt, R., Macpherson, A., \& Pittaway, L. (2005). Using knowledge within small and medium-sized firms: A systematic review of the evidence. International Journal of Management Reviews, 7(4), 257-281.

Tranfield, D., Denyer, D., \& Smart, P. (2003). Towards a methodology for developing evidence-informed management knowledge by means of systematic review. British Journal of Management, 14(3), 207-222.

Ulijn, J., \& Fayolle, A. (2004). Towards cooperation between European start-ups: The position of the French, Dutch and German entrepreneurial and innovative engineer. Innovation, entrepreneurship and culture: The interaction between technology, progress and economic growth, 204-232.

Van de Ven, A. H., \& Polley, D. (1992). Learning while innovating. Organization Science, 3(1), 92-116.

Vargas-Halabí, T., Mora-Esquivel, R., \& Siles, B. (2017). Intrapreneurial competencies: Development and validation of a measurement scale. European Journal of Management and Business Economics, 26(1), 86-111.

Vermeulen, P. A., De Jong, J. P., \& O'shaughnessy, K. (2005). Identifying key determinants for new product introductions and firm performance in small service firms. The Service Industries Journal, 25(5), 625-640.

Wang, M. (2010). Influence of knowledge sharing and project complexity on group creativity: taking the development of information system for example. Journal of e-Business, 12(1), 73-102.

Watson, D., \& Clark, L. A. (1997). Extraversion and its positive emotional core Handbook of personality psychology (pp. 767-793). Elsevier.

Wiklund, J., \& Shepherd, D. (2003). Knowledge-based resources, entrepreneurial orientation, and the performance of small and medium-sized businesses. Strategic Management Journal, 24(13), 1307-1314

Williamson, J. M., Lounsbury, J. W., \& Han, L. D. (2013). Key personality traits of engineers for innovation and technology development. Journal of Engineering and Technology Management, 30(2), 157-168.

Woo, H. R. (2018). Personality traits and intrapreneurship: the mediating effect of career adaptability. Career Development International, 23(2), 145-162.

Zahra, S. A., \& Nielsen, A. P. (2002). Sources of capabilities, integration and technology commercialization. Strategic Management Journal, 23(5), 377-398.

\section{Publisher's Note}

Springer Nature remains neutral with regard to jurisdictional claims in published maps and institutional affiliations.

\section{Submit your manuscript to a SpringerOpen ${ }^{\circ}$ journal and benefit from}

- Convenient online submission

- Rigorous peer review

- Open access: articles freely available online

- High visibility within the field

- Retaining the copyright to your article

Submit your next manuscript at $\boldsymbol{\sim}$ springeropen.com 